\title{
The Influence of Culture on the Realization of Education for All (EFA) among the Baila people of Namwala, Southern Province, Zambia
}

\author{
Patrick C. Muma* \\ Department of Educational Administration and Policy Studies, the University of Zambia, Lusaka, Zambia \\ Peter C. Manchishi \\ Department of Language and Social Sciences Education, the University of Zambia, Lusaka, Zambia
}

*Corresponding Author: Patrick C. Muma, Department of Educational Administration and Policy

Studies, the University of Zambia, Lusaka, Zambia, Email: Shichota@yahoo.com

\begin{abstract}
The article explores the influence of traditions on the realisation of Education for All (EFA). It is based on the study which was carried out among the Baila people of Namwala district in the Southern Province of Zambia. The article identifies four main traits or beliefs of the Baila and demonstrates how these traditional practices and traits have negatively impacted on the actualisation of Education for All in Namwala. The article intends to show that for any developmental interventions to take place, it is imperative that the local people's cultures and traditions are taken into consideration.
\end{abstract}

Keywords: Tradition, Culture Education, Pastoralism, Conservative, self-Reliance, Community Participation.

\section{INTRODUCTION}

Tradition or culture is taken to be one of the defining factors of who a people are. UNESCO (2001) defines culture as encompassing distinctive aspects of a group of people and includes their value systems, traditions and beliefs. In addition, culture brings out the spiritual, material, emotional and the intellectual facets of a group of people. UNESCO's definition of culture implies that the value system of a society and their worldview is, to a greater extent, influenced by their culture or tradition. It then follows that even the reaction or responses of a social group to such things as developmental issues like education would draw from their reservoir of their traditions. Consequently, those societies which have traditions favourable to acquisition of formal education are likely to perform well and have an educated community. Inversely, those societies whose traditions are inimical to developmental trends dictated by the hegemonic Western world find it difficult to fit in and keep up the pace of development.

This paper is based on a study which examined the influence of tradition on the realisation of Education for All (EFA). Basing itself on the case of the Baila people of Namwala in the Southern Province of Zambia, the study endeavoured to examine the compatibility of the Baila traditions to the acquisition of modern formal education. In addition, the study suggested ways in which the Western hegemonic education could be attractive to the local people.

The study was born out of the desire to find out why Namwala, the traditional dwelling place of the Baila, had a very low enrolment and retention rate. Primary data at the same time showed that absenteeism from school among boys and girls was rife. In addition, there was a high drop-out rate among girls due to early marriages and teenage pregnancies. Consequently, the whole district performed poorly in all the national examinations in the five years that the research restricted itself to. At the Grade 7 and 9 levels, the district was within the bottom three out of eleven districts in the province and always below the national average. A quick inquiry from the teachers laid the blame on the traditional practices of the Baila, that they were traditionally not interested in education. So the study set out to investigate the Baila traditions and how they affected the realisation of Education for All. 


\section{The Baila People}

The Baila people, the subject of the discussion in this paper, are a pastoral tribe found in Namwala district in the Southern province of Zambia. Although oral history traces the Baila as originating from South of Sudan, the mythology of the traditional Baila, according to Smith \& Dale (1920) depicts their ancestors as having dropped from the sky and landed at a rocky place called Bwengwa-Leza where foot prints of people and animals are said to be found. Bwengwa-Leza, literally means "God's creation." The Baila believe God created them in the sky and dropped them in Namwala. They claim they did not migrate from anywhere outside Namwala. This belief makes the Baila people claim to be the most indigenous people in Zambia.

The Baila are a unique social grouping. The same, however, can be said about each social grouping. Massey (1979) asserts that there are distinctive features that can be identified in each social grouping which gives meaning to their lives and sets them apart from the other people. The study on which this paper is based identified five distinctive traits which form part of the traditions of the Baila and by which the persona of the Baila is crafted. The Baila are keen pastoralist. At the same time they are identified to be a very conservative people, proud and individualistic. The other part of the traditions of the Baila is that they are hardworking and self-reliant.

\section{Method}

The study adopted a qualitative descriptive research design which incorporated semi-structured interviews, document analysis, Focus Group discussions and ethnography. A wide spectrum of stakeholders who included the traditional chiefs, head men, head teachers, teachers and pupils were involved in the study. Other participants were representatives of some Non-Governmental Organisation with a noticeable influence in education in Namwala and some other community members that were deemed crucial in the study. The total number of participants was 81.Purposive sampling was employed as the best way of selection of participants. The objective of the study was to analyse the compatibility of the traditional Ila worldview with the goals of Education for All. In other words the study addressed itself to inquiring if and how the traditions of the Baila people influenced the realisation of EFA.

\subsection{Objectives of the Study}

The study had three main objectives:

a. To assess the influence of the Ila tradition on access to formal education

b. To assess the influence of the Ila tradition on academic performance.

c. To analyse the compatibility of the traditional Ila worldview with the goals of EFA.

\subsection{Research Questions}

The study sought to answer the following questions:

a. What is the influence of the Ila tradition on access to formal education?

b. What is the influence of the Ila tradition on academic performance?

c. What is the compatibility of the Ila tradition with the goals of EFA?

However, this article is mostly based on the third objective of the study and its corresponding research question.

\section{THEORETICAL FRAMEWORK}

The study was anchored on two theories; namely the Human Capital theory which promotes investment in human beings as the fastest way of accelerating development. According to this theory, education is the most reliable vehicle through which development can be realised. Consequently, Fagerlind \& Saha (1995, p.18) argued that, "education does not only improve the individual choices available to men, but that an educated population provides the type of labour forces necessary for industrial development and economic growth.” 
Likewise, World Bank (2011, p.1) supports the Human Capital Theory and identifies education as fundamental to development and growth. And in its exaltation of education as a key pillar in human growth and development, World Bank implores developing countries to invest in education if growth in health, agriculture and infrastructure is to be a reality in the lives of their citizens. The Human capital theory emphasises that education is not a form of consumption to government but an investment which improves the economic worth of the individuals and ultimately the whole society. The underlying principle of the Human Capital theory is that man plays a pivotal role in any form of development and because education adds to the dignity of man, it should be offered to all. And since a society sees the world through the values it holds, education adds to the unlocking of that society's potential only when the education offered is in tandem with its values. Consequently, it can be argued that education for development should be considered as being contextual to the group of people it is offered to as its being appreciated by them depends on the value which that particular group of people places on it. The value that the hegemonic West places on education as a tool for development makes it attractive and mandatory that it be offered to all.

The Human capital theoretical framework was relevant to this study because it interrogated whether the Ila traditional life, which does not seem to value Western formal education, can be seen as leading to any form of personal and societal development in the modern understanding of development.

The other theory which guided the study is the African Indigenous Knowledges Theory (AIK). Indigenous Knowledges, according to Semali \& Kincheloe (1999:3) “...reflect the dynamic way in which the residents of an area have come to understand themselves in relationship to their natural environment and how they organise that folk knowledge of flora and fauna, cultural beliefs and history to enhance their lives." Indigenous knowledges therefore promote the culture and traditions of the local people and emphasises that these knowledges and practices need to be respected and recognized as treasures which can contribute to the development of the society.

The AIKS theory was considered in this study because it, somehow, contrasts with the human capital theory's emphasis on formal Western education as the main way in which any form of economic and social development can be realized in a society. The Indigenous Knowledges Systems expound that a people can develop fully by making use of their indigenous knowledges without necessarily completely falling back on Western knowledge productions at the expense of their innate knowledges. The AIKS theory illuminates the concept that human development does not take place only within the hegemonic Western education discourse.

\section{RESULTS AND DISCUSSION}

The study examined some cultural practices and beliefs which form part of the lenses through which the traditional Baila see the world. The study was guided by the objective of finding out the compatibility of the Baila tradition with modern formal education. This section discusses the prominent features of the Baila's traditions in relation to Western formal education.

\subsection{Baila as Pastoralists}

Pastoralism is a way of life which is quite common in many developing countries. The search for pastures for the animals makes some pastoralists nomads. However, the degree of nomadism varies. There are those where the whole family moves in search of pastures like the case of the Masai in Kenya (Orodho, 2014) while others like the Baila in Namwala have permanent homes but the children who take the cattle in the plains for pastures, they call lutanga, are the ones who are constantly on the move. Be it as it may, there are some common traits that are found among pastoralist which are derived from the way they value their animals. For instance, there seems to be a lot of commonalities in the way pastoralists regard their children (Smith \& Dale, 1920; Jaspan, 1953; Lawman, 1958; Dyer, 2001; Orodho, 2013; Suri, 2014). It seems the value of their children is related to the way they take care of their cattle, in the case of boys, or the number of heads of cattle they are able to bring to the family in the form of bride wealth, lobolain the case of girls. Consequently, the number of days these children are allowed to remain in school has a bearing on the value for cattle. For example, a girl can be withdrawn from school any time she attains the age of puberty to get married so that the family can benefit from the bride wealth. This could be as early as at the age of 12 years. This traditional 
The Influence of Culture on the Realization of Education for All (EFA) among the Baila people of Namwala, Southern Province, Zambia

practice implies that the girl's value in the family hinges very much on her being married so that cattle can be paid in exchange for her hand in marriage. And so, traditionally, the Baila call a girl MukaBanjiBanji, which means a girl's role is to attract many men. In the same vein, the Baila have a saying that mukaintuninteshoyalubono, which literally translates that 'a woman is a source of wealth.' The wealth referred to here is cattle. It is for this reason that Smith\& Dale (1920, p. 2) assert that among the Baila, “... girls are regarded as riches only, that is, as so many cattle to the credit of the clan's account."Consequently, early marriages are encouraged or preferred among the traditional Baila and formal education is frowned upon and regarded as a delay in the acquisition of wealth. This situation among the Baila is similar to the Mandera nomadic pastoralists in Kenya who believe that educating a girl is a waste of resources and a risky venture because the more the girls are educated, the less the chances of them getting married (Orodho, 2014).

On the other hand, boys are regarded as shepherds. The Ila- English dictionary calls boys of about 7 and 8 years as kembezhior shikembezhi. Those older than 14 years are referred to as mwembezhi (Smith, 2011, pp271-272). The word bembezhialso means a shepherd or herdsman. This has a very deep meaning concerning the position of boys in the traditionallla society especially when it is considered that the life of the Baila oscillates around the rearing of cattle. The implication is that a boy around this age group is considered being of value only when he can take care of cattle. However, during this same age group, a boy is supposed to be in school but his tradition forces him to be absent from school for as long as a whole term when the family decides that his services are required at the lutanga to herd cattle. In the case of the Mandera pastoralists in Kenya (Orodho, 2014) it is the intelligent boys who are kept out of school because it is believed they know how to count well and can therefore make accurate account of the animals. When pastoralists reserve the best brains for taking care of their cattle, it implies that that is where the best returns for their investments are found. This justifies the Baila's claim that when they have cattle, formal education is least regarded.

Namwala, the traditional home of the Baila has the highest number of cattle compared to any district in Zambia, and the Baila have remarkable skills in cattle rearing (Smith \& Dale). The study established that the pastoral nature of the Baila has great impact on their attitude to education. The gist of Baila perception of education is better summarised by a participant in a study by Heinzer (2011, p. 46) who, when asked why the Baila seem not to be interested in formal education responded, "Education is a form of wealth, wealth which the Baila already possessed through their cattle. The pride and independence made possible by prosperity made the necessity of school education unjustified." This statement seems to underpin all the realities about education which most traditional Baila hold. At the same time the statement suggests a mentality of doubts about the credibility and relevance of the education offered (Banda, 2008, Serpell, 1993). There is a general belief among the Baila that education is not just acquired for its own sake or for self-actualization but that it should lead to social mobility by getting a salaried job. So, it follows that if rearing cattle can provide the material comfort and self-esteem within the community which one would get if they got a salary because of the education they acquired, then there was no need of leaving the traditional comfort zone and go through the huddles of formal education system. To this effect, one traditional chief in our study illustrated why education among the Baila received very little attention in the following words:

Education is not envied. It has no value because even the educated people who have gone to towns for work come back to the villages to get resources from the kraal whenever a calamity befalls them. It has become very common to see the educated town dwellers come back to ask for some cattle to be sold when they want to send their children to school, to repay a debt or even to buy a car. It seems cattle have better currency than the money education brings through salaried employment. So the young villagers are not inspired by the educated.

Similarly, Bishop (2007, p. 20) in her study of the Masai of Tanzania blames the indifference of pastoralist communities to formal education on the irrelevance of the curriculum offered, "...school curricula are largely irrelevant to pastoralists' experience and concerns. Low relevance generates low interest and lowers motivation, causing low enrolment figures and high dropout rates." On the issue of relevance of the curriculum a participant in our study argued that: 
The Influence of Culture on the Realization of Education for All (EFA) among the Baila people of Namwala, Southern Province, Zambia

\begin{abstract}
Education is not appreciated because it is not relevant to the Baila's way of life. Academic education does not mean much. If vocational skills, especially those leading to good animal husbandry were taught in schools, all the classrooms in Namwala would always be full.
\end{abstract}

Another negative aspect of the pastoral tradition in connection with education is that the attachment which pastoralists have to their animals inhibits them from converting their animals into cash which can be used in the education of their children. While Zambia, in the spirit of Education for All declared free education for learners from Pre-school to Grade 7 (Examinations Council of Zambia, 2013), the reality on the ground is that certain activities and services in school are paid for by the parents through Parent Teachers Association fees because the government cannot manage to provide free services to all (Kelly, 2010). Many Ilachildren fail to go to school because of failure by their parents to pay school fees even when they have a lot of cattle. Lawman, 1958 and Smith \& Dale, 1920 assert that the Baila regard cattle as part of their family and would only sell in very desperate situations, of which paying school fees ranks very lowly. Similarly, the quest for a big herd of cattle at the expense of the ability to use them for their social and economic development is common ground for the transhumant pastoralists in Western India (Dyer, 2001). The attitude of pastoralist communities in relation to their cattle and formal education is well summarised by Orodho $(2014, \mathrm{p}$. 112) who states that, "families do not view their livestock in monetary terms and are reluctant to sell them for education purposes. Above all, large herds are viewed as symbols of prestige that cannot be sold to purchase education."

\title{
5.2. Conservative Nature of the Baila
}

Our field work brought out the conservative nature of the Baila. Related literature also confirmed this traditional trait. Smith \& Dale (1920, p. 344) state that an Ila "...grows up to fear and resent change; from the cradle to the grave he is ruled by custom." Similarly, Smith (1946) and Nkumbula (1961) ascertain the conservative nature of the Baila. It is worth noting that this conservative nature of the Baila has a deep background. Smith \& Dale (1920, p. 345) profess that the Baila follow custom because of two reasons. The first one is that they follow customs because they were spelt out by God for a special reason "ShifundoshaLeza" and not following these precepts could mean calling upon God's wrath on oneself. This profession must be understood in the backdrop that for Africans there seems to be no boundary between the religious and the temporal (Chabal \&Daloz). The second reason is that they believe some of their traditions were established by their departed ancestors, Mizhimo. There is a deep belief that the ancestors must have had very strong reasons for establishing those customs; and going against them could be regarded as an insult to the spirits who can punish them for that. The second reason is later amplified and generalised by Smith (1946, pp.56-57) who points out the exulted position the living dead, or ancestors play in the value formation in an African society. About the ancestors, he summarises, "...they are in a peculiar sense custodians of the tribal traditions; any departure from the established order of things without their consent is an offence against them." Similarly, Breidlid (2009) amplifies the important role that ancestors play in the African spirituality as guarantors of social and moral wellbeing as well as promoters of solidarity of a society.

The habit of sticking to tradition and not being open to change has been detrimental to the development of education among the BailainNamwala. While the early missionaries with their schools reached Namwala in the early part of $19^{\text {th }}$ Century (Smith \& Dale, 1920) the effect of their presence has been negligible in the education sphere. Snelson (1974: 21) justifies the failure of missionaries to have an impact in the education of the Baila. He submits, "Where a school was considered by the community to have scant relevance to their socio-economic pattern there was very little the mission educationists could do about it." As earlier alluded to, access to education has been very low in Namwala. There is a general belief among the traditional Baila that if their forefathers lived very honourable and satisfying lives even without Western formal education, the present generations could similarly do so as long as they have cattle.

Being conservative, in itself, is not a bad traditional quality. Maalouf (2003, p. 102) calls it a very normal trend among human beings. He calls it a beginning point for creation of personal and societal identity. And cautioning against wholesome modernisation which seems to be synonymous with globalisation, Maalouf (2003: 79) questions, "How can we modernise ourselves without losing our 
identity? How can we assimilate Western culture without denying our own? How can we acquire West's knowledge without leaving ourselves at its mercy?" However, the conservative nature of the Baila inhibits them from responding quickly and positively to the changing trends in education. The study showed that many Head teachers faced a lot of challenges convincing the parents to actively participate in the improvement of the learning environments where their children go by contributing some money or being part of the community work at school. It was reported that many believed the provision of such facilities was best left in the hands of the government.

However, on the issue of pastoralists being indifferent to formal education, Bishop (2007) has a different view. She argues that the perceived reluctance of pastoralists to embrace formal education should not be attributed to their conservatism. To support her assertion, Bishop (2007, p. 20) cites Purkipung ( 1975: 44) who argued that the Tanzanian Masai have felt that formal education erodes pastoral values: "It is not school that they hate but the effects of such education in the culture, integrity and values of the society." This statement resonates well with what Chief Mukobela of the Baila people said about education when he stated that Western formal education had done the Baila children little good except to teach them to be rude to the elders (Lawman, 1958). So it is this clear dichotomy between what the young learners know at home and what they are taught in school which makes some traditional Baila resist the formal education as a way of preserving the traditional values they hold dearly. Breidlid (2013) calls this dichotomy as "daily crossing of epistemological borders" on the part of the learners. And condemning the lack of relationship between what is taught in school and the lived realities of the learners, Banda (2008) argues that, "if schools cannot teach children about their society and shape their values and ambitions and learning patterns, they should be abolished."

\subsection{Proud and Individualistic}

Another traditional trait which sets the Baila apart is that they are purported to be individualistic (Lawman, 1958; Smith \& Dale, 1920). The latter even made an assertion that the Baila have never been a united people (1920). All the traditional chiefs in the study admitted that the Baila were generally a very proud people and that their pride mostly emanated from the cattle they keep in large numbers.

Oral history of the Baila shows that they have mostly been individualistic and have had very weak affinity to chieftainship (Lawman, 1958). However, Smith \& Dale (1920) attribute the individualism, which they link to isolation, as stemming from the Baila's geographical location of being in a plain area. They extrapolate that when their habitat, the plain is flooded; it restricts their movements and ultimately forces them to develop a sense of independence and self-satisfaction.

The individualism and pride of the Baila negatively affects the execution of modern education in that community participation which Education for All advocates (Kelly, 2010) is not realised. Head teachers in the study complained of very low turnout for PTA meetings. According to one participant, pride is even taken to the level where when communal work is called for, some Bailatact fully check which class of people had reported at the place of work before them. If it is people of low status, one with a higher standing in society would not join the group. In addition, there was evidence provided in the research where some youths dropped out of school because they could not conform to the discipline required of them in school. They claimed they were rich with the herds of cattle their parents had and could, therefore, not be subjected to what they called 'humiliation' of following school rules which sometimes called for physical or manual punishment when not adhered to.

The pride of the Baila also had a negative impact on the goals of EFA in that the illiterate adults in the study, particularly the men still said they could not join Adult education classes which were being offered. Some of them felt ashamed to publicly show that they were not educated while others dwelt much on the irrelevance of formal education in their lives. One participant shared the following:

\footnotetext{
"What is the use of going to school? I did not go to school but I have more cattle than some of my friends who completed Grade 12. I stopped school in Grade 5 but I am rich. I have three wives and twelve children. The people here respect me. I have even helped some of my educated friends with money because they have no jobs. I can even employ some of them if I wanted. It is good I did not waste time learning things which do not even help me."
} 
Individualism is further exacerbated by their preoccupation in pastoralism which requires them to live a good distance away from each other so that their cattle could have enough pastures. This practice affects the provision of schools; for schools are economically established in areas where the population is dense enough. Where schools are established in sparsely populated areas, for political expedience in most cases, the facilities are not properly and economically utilised. This, at the same time, makes many pupils walk long distances to access school thereby leading to rampant absenteeism. To get round the problem of establishing expensive permanent schools which are poorly attended by children of pastoralists governments in Kenya, Tanzania and Kashmir, for example have opted to provide mobile schools (Orodho, 2014; Suri, 2014; Dyer, 2001).However, these mobile schools are not cheap to run and so sustainability of the mobile schools has proved to be a challenge.

\subsection{Hardworking and Self-Reliant}

Most Baila participants in the study submitted that the Baila were traditionally hardworking and selfreliant. The two qualities stem from the feeling of self-important especially for those who have acquired a reasonable number of cattle. In themselves, these qualities are positive and progressive. Developed countries today like China and the United States of America boast that they have reached their state of economic and social development because their citizens have embraced these two traits in their lives. However, the amplification of the term 'self-reliant' as one Chief in the study explained gives it a negative connotation in the modern world of cooperation. The chief expounded on the term and stated that, "An Ila is self-reliant. He believes he does not need any other person or thing to have a good life, as long as he has animals..." In the same breath, the same Chief narrated that cooperatives had failed in Namwala partly because of this over exaggerated self-reliance where each individual thinks he or she does not need the neighbour to survive. So, herein lies the negative part of a traditional value which on face value is supposed to be positive. The self-reliance in this case has some shades of individualism which has been discussed above. Modern formal education, while promoting the personal aspiration of an individual calls for community participation in its delivery, especially in infrastructure development and provision of teaching and learning materials, as alluded to earlier. So, an exaggerated self-reliance by many traditional Baila has hampered the actualization of Education for All in Namwala because it compromises quality which could be enhanced if the community worked together for a common goal.

\section{RECOMMENDATIONS}

It cannot be denied that the Western hegemonic education depicts other cultures as being inferior. The lack of interest in Western formal education by some people could partly be because of the power differences it demonstrates between the implementers or advocates of this formal education and the indigenous recipients of this education. In his study of the Maori people of New Zealand, Bishop (2003) demonstrated how the perceived inferior culture of the Maori could be mainstreamed into the formal education offered to them. Bishop suggested a model which emphasised empowerment of the indigenous people and a notion which demonstrates that culture is an important element of a person's life and should therefore be co-constructed by teachers who wedge power in the classroom together with the pupils who are mostly on the weak receiving end of the spectrum.

The study among the Baila in Namwala observed that traditional knowledge which the pupils brought to the classroom was in most cases not given any attention by the teachers. It can be argued that the traditional notion of cattle rearing, for example, could have a different impact on education if the teachers took time to positively discuss the traditional view of cattle business and life to reconstruct it in such a way that the modern socio-economic ways of cattle rearing were implanted into the learners without necessarily watering down the traditional views concerning the same. Doing so could bring the element of relevance in modern formal education which many participants confessed was missing in the current content and mode of delivery of education. The irrelevance of the modern formal education to the survival of some indigenous people made Dyer question whether the states and organisations championing EFA were making similar undertakings to create employment which their graduates would live on if the traditional occupations were edged out by the development they advocated through the formal education.

The traditions and cultures of the indigenous peoples would no longer be impediments in the realisation of Education for All if the implementers or advocates of the same education realised and 
practised the aspect that education should bring about development within a people's milieu and not otherwise. When development is only understood as perceived in the Western discourse, it becomes alien to many indigenous people. This is the notion which Gegeo(1998) brings to the fore when he argues against the classic modernization theory which asserts that third world peoples should break free of their traditional institutional structures to embrace Western values and social formation if they have to develop. Gegeo(1998, p. 291) proposes a change from within: "The change that I mean is that which villagers themselves bring about. It may involve borrowing from outside knowledge or ideas, but in a very essential way it emerges from their own perspectives, cultures and languages."Gegeo's assertion, somehow, brings in the essence of the Human capital theory being realised through formal education which is implied by his use of the term 'borrowing from outside knowledge or ideas' but he insists the development should be within the indigenous knowledge of the local people, which is their own perspectives, cultures and languages.

\section{CONCLUSION}

Education is believed to be one of the interventions which bring about accelerated development in a society. An educated citizenry actively and positively participates in the social, economic and political wellbeing of a society. One's traditions sometimes influence their perception or appreciation of education, for it is through the traditional lenses that the world is perceived. This article has, therefore, attempted to highlight how the traditional values and practices can affect the appreciation of Western formal education. So, taking a case of the Baila people of Southern province of Zambia, the paper has shown how the tradition of pastoralism and conservatism has negatively affected the actualisation of Education for All among the Baila. It is because of these traditions that the Baila have come to doubt the relevance and credibility of the modern Western education which is offered.

In addition, the article has discussed how pride, individualism, hardworking spirit and a sense of selfreliance can be a hindrance in the realisation of Education for All when a society exaggerates these inherently positive attributes. In the case of the Baila, especially in relation to the way they regard their cattle, it can be concluded that when a community or tribe has a deep rooted theory or value system which is wealth- generating; it can impact negatively on their appreciation of formal education particularly where education is only regarded as a means of mobility or getting a job for ones' sustenance.

It then follows that for any developmental intervention to take root in the intended people, it is imperative that the traditions and cultures of the local people are considered. It is on this premise that Chivaura (2006) condemns the belief that Western solutions wholesomely deal with African problems. Chivaura argues, “... The danger of adopting the European worldview to solve African problems is therefore obvious. It is hostile to our worldview and idea of development. African development can only be achieved through an African worldview." It can, thus be concluded that for the Western hegemonic formal education to have a positive impact on the indigenous people, it should consider some strong local cultures and traditions and try to mainstream some of them in the education system while gently and humanely trying to adapt those which are deemed to be completely inimical to the education dispensation.

\section{REFERENCES}

[1] UNESCO. Universal Declaration on Cultural Diversity. Paris: UNESCO.(2001)

[2] Smith, E \&Dale.. The Ila-speaking Peoples of Northern Rhodesia (Vol. I). London: Macmillan and Co., Ltd, 1920. P.31

[3] Massey. J. Concerning Christian Unity, Niagara Falls, Warmer, 1979, p.79

[4] Fagerlind, I\& Saha. Education and National Development: A Comparative Perspective.Oxford: Heinemann. 1995. P 18

[5] World Bank Group Education Strategy2020. Learning for All: Investing in People's Knowledge and Skills to Promote Development .Washington: The World Bank. 2011. P.1

[6] Semali, L\&Kincheole. Introduction: What is Indigenous Knowledge and why should we study it? In What is Indigenous Knowledge?: Voices from the Academy ( $\left({ }^{\text {st }} \mathrm{Ed}\right)$. London: Routledge (1999) p.3

[7] Orodho, J et al. (2014). Progress towards attainment of Education for All (EFA) among the Nomadic pastoralists: How do we dismantle the gender differential jinx in Mandera count, Kenya? Journal of Humanities and Social Science, 19(2), 106-117. 
The Influence of Culture on the Realization of Education for All (EFA) among the Baila people of Namwala, Southern Province, Zambia

[8] Smith, E \& Dale. The Ila-speaking Peoples of Northern Rhodesia (Vol. I). London: Macmillan and Co., Ltd.1920

[9] Jaspan, M.A. The Ila-Tonga peoples of North-Western Rhodesia. London: International African Institute. 1958

[10] Lawman, T. W. The Long Grass. London: Robert Hale Ltd. 1958

[11] Dyer, C. Nomads and Education for All: Education for Development or Domestication? Comparative Education, 37(3), 315-327 (2001).

[12] Orodho, J et al. Progress towards attainment of Education for All (EFA) among nomadic pastoralists: Do home-based variables make a difference in Kenya? Research on Humanities and Social Sciences, 3(21), 54-67 (2013)

[13] Suri, K. Education, conflict and development: A case study of mobile schools for pastoralists in Jammu and Kashmir. Journal of Research \& Method in Education, 4(1 Ver. V), 12-19 (2014).

[14] Smith, E \& Dale. The Ila-speaking Peoples of Northern Rhodesia (Vol. I). London: Macmillan and Co., Ltd.1920. p. 2

[15] Orodho, J et al. Progress towards attainment of Education for All (EFA) among the Nomadic pastoralists: How do we dismantle the gender differential jinx in Mandera count, Kenya? Journal of Humanities and Social Science, 19(2), 106-117(2014).

[16] Smith, E. W. A Handbook on the Ila Language. London: LINCOM. pp 271-272. 2011

[17] Orodho, J et al. Progress towards attainment of Education for All (EFA) among the Nomadic pastoralists: How do we dismantle the gender differential jinx in Mandera count, Kenya? Journal of Humanities and Social Science, 19(2), 106-117 (2014).

[18] Smith, E \& Dale. The Ila-speaking Peoples of Northern Rhodesia (Vol. I). London: Macmillan and Co., Ltd. 1920

[19] Heinzer, L. The Culture of the Baila. Einsiedeln.( Unpublished) 2011

[20] Banda, D. Education For All (EFA) and the 'African Indigenous Knowledge Systems (AIKS)': The case of the Chewa people of Zambia. University of Nottingham, Nottingham.(2008)

[21] Serpell, R. The significance of schooling. Life-Journeys in an African Society. Cambridge: Cambridge University Press. 1993

[22] Bishop, E. Schooling and Pastoralists' livelihoods: A Tanzanian case study (Thesis for Doctor of Philosophy degree). University of London, London. Pp. 20

[23] Examinations Council of Zambia. Research Study on Learner Absenteeism from Public Examinations: An Inquiry into the Extent and Causes of Absenteeism at the Primary and Junior Secondary School (Study). Lusaka: ECZ. 2013

[24] Kelly, M. The Origins and Development of Education in Zambia (second). Lusaka: Image Publishers Ltd.2010

[25] Lawman, T., W. The Long Grass. London: Robert Hale Ltd. 1958

[26] Smith, E \&Dale.. The Ila-speaking Peoples of Northern Rhodesia (Vol. I). London: Macmillan and Co., Ltd. 1920

[27] Dyer, C. Nomads and Education for All: Education for Development or Domestication? Comparative Education, 37(3), 315-327 (2001).

[28] Orodho, J et al. (2014). Progress towards attainment of Education for All (EFA) among the Nomadic pastoralists: How do we dismantle the gender differential jinx in Mandera count, Kenya? Journal of Humanities and Social Science, 19(2), p. 114 (2014)

[29] Smith, E \& Dale. The Ila-speaking Peoples of Northern Rhodesia (Vol. I). London: Macmillan and Co., Ltd. P. 344. 1920

[30] Smith, E. W. Knowing the African. London: United Society for Christian Literature.1946

[31] Nkumbula, H Life and Customs of the Baila (Unpublished) 1961

[32] Smith, E \& Dale. The Ila-speaking Peoples of Northern Rhodesia (Vol. I). London: Macmillan and Co., Ltd. 1920. P.345

[33] Chabal, P\&Daloz. Africa Works: Disorder as Political Instrument. Oxford. Oxford University Press. 1999 .P.65

[34] Smith, E. W. Knowing the African. London: United Society for Christian Literature.1946. Pp.56-57

[35] Breidlid, A. Culture, indigenous Knowledge systems and sustainable development: A critical view of education in African context. International Journal of Educational Development 29 .p.141. (2009).

[36] Smith, E. W. Knowing the African. London: United Society for Christian Literature. 1920

[37] Snelson, P. D. (1974).Educational Development in Northern Rhodesia 1883-1945 (Second). Lusaka: Zambia Educational Publishing House. 1974. P.21

[38] Maalouf, A. In the name of identity. London: Penguin Books. 2003

[39] Maalouf, A. In the name of identity. London: Penguin Books. 2003. P.79

[40] Bishop, E. Schooling and Pastoralists' livelihoods: A Tanzanian case study (Thesis for Doctor of Philosophy degree). University of London, London.P.20 (2007) 
The Influence of Culture on the Realization of Education for All (EFA) among the Baila people of Namwala, Southern Province, Zambia

[41] Lawman, T., W. The Long Grass. London: Robert Hale Ltd. 1958. P.137

[42] Breidlid, A. Education, Indigenous Knowledges, and Development in the Global South. New York: Routledge. 2013

[43] Banda, D. Education For All (EFA) and the 'African Indigenous Knowledge Systems (AIKS)': The case of the Chewa people of Zambia. University of Nottingham, Nottingham.(2008)

[44] Lawman, T., W. The Long Grass. London: Robert Hale Ltd.1958

[45] Smith, E \& Dale. The Ila-speaking Peoples of Northern Rhodesia (Vol. I). London: Macmillan and Co., Ltd. 1920

[46] Kelly, M.The Origins and Development of Education in Zambia (second). Lusaka: Image Publishers Ltd. 2010. P.167

[47] Orodho, J et al. Progress towards attainment of Education for All (EFA) among the Nomadic pastoralists: How do we dismantle the gender differential jinx in Mandera count, Kenya? Journal of Humanities and Social Science, 19(2), 106-117.( 2014)

[48] Suri, K. Education, conflict and development: A case study of mobile schools for pastoralists in Jammu and Kashmir. Journal of Research \& Method in Education, 4(1 Ver. V), 12-19.(2014)

[49] Dyer, C. Nomads and Education for All: Education for Development or Domestication? Comparative Education, 37(3), 315-327.( 2001)

[50] Bishop, R. Changing Power Relations in Education: Kaupapa Maori messages for 'mainstreaming' education in Aotearoa/ New Zealand. Comparative Education, 39(2), 221-238(2003)

[51] Dyer, C. Nomads and Education for All: Education for Development or Domestication? Comparative Education, 37(3), 315-327.(2001)

[52] Gegeo, D., W. Indigenous Knowledge and Empowerment: Rural Development examined from within. The Contemporary Pacific, 10(2), P. 291.( 1998)

[53] Chivaura, V. African indigenous worldviews and ancient wisdom: A conceptual framework for development in Southern Africa. In: Kunnie, J \&Goduka, N (Eds), Indigenous Peoples' Wisdom and Power: Affirming our Knowledge ThroughNarratives. Hampshire: Ashgate Publishing P.217 (2006).

\section{AUTHORS' BIOGRAPHY}

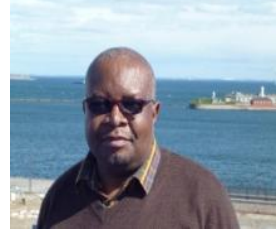

Patrick Muma, currently works in the Ministry of General Education as Principal Education Officer (HQ). He holds a Masters degree in Multicultural and International Education from Oslo and Akershus University College of Applied Sciences (Norway), a Bachelor of Arts with Education degree from the University of Zambia and a Diploma in Education from Nkrumah Teachers College. He is a $\mathrm{PhD}$ candidate in Education and Development at The University of Zambia. His main research interest is in education and indigenous knowledges.

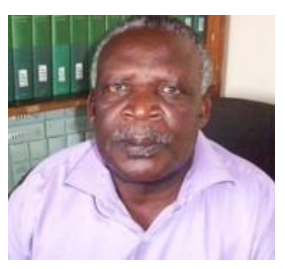

Dr. Peter Manchishi, is a Senior Lecturer in the School of Education at the University of Zambia. He holds a PhD, MA and BA in Applied Linguistics from the University of France-Comte at Besancon in france. His research interest is in Language and Teacher Education

Citation: Patrick C. Muma and Peter C. Manchish. "The Influence of Culture on the Realization of Education for All (EFA) among the Baila people of Namwala, Southern Province, Zambia" International Journal of Humanities Social Sciences and Education (IJHSSE), vol 4, no. 9, 2017, pp. 88-97. doi: http: //dx.doi.org/ 10.20431/2349-0381.0409011.

Copyright: (C) 2017 Authors. This is an open-access article distributed under the terms of the Creative Commons Attribution License, which permits unrestricted use, distribution, and reproduction in any medium, provided the original author and source are credited. 